\title{
ANALYSIS OF SURGICAL TREATMENT FOR WOMEN WITH BREAST CARCINOMA OF DIFFERENT DIAMETERS
}

\section{ANALIZA HIRURŠKOG LIJEČENJA KARCINOMA DOJKE RALIČTOG DIJAMETRA KOD ŽENA}

\author{
Predrag Lazić1, Darko Lukić2, Duško Ivić3 ${ }^{3}$ Nenad Babić2 , Spomenka Paurević
}

\section{Summary}

The prospective study, lasted from January 2010 to January 2015, covered the respondents treated for breast carcinoma. The respondents were divided into 2 groups. First group, group A (59 respondents), included the respondents where the tumour was found in diameter to $2 \mathrm{~cm}$ and were operated by breast-sparing surgery. Second group, group B (88 respondents), was consisted of respondents where the tumour was discovered in diameter over $2 \mathrm{~cm}$ and which breast amputated as part of a radical cancer surgery by Madden technique.

The aim of this study is to analyse the effects of surgical treatment of breast carcinoma with different diameter and influence of tumour diameter on treatment outcome.

The parameters for comparison of results were the number of relapses, the time elapsed from surgery to recurrence and treatment outcome.

There were no significant differences between the two groups regarding the motives for attending breast examination. The incidence of carcinoma in the left or right breast also showed no statistical difference.

It was found that the most common breast cancer is in women age between 50 and 70 . It has been shown that breast carcinoma with diameter over $2 \mathrm{~cm}$ was significantly more frequent in women age of 71 to 80 .

Recurrent disease was registered in 3 cases in respondents from group A. Recurrence in group $B$ was not registered.

Lethal outcome was observed in group B in 4 cases, and in group $A$ in 1 case, which proved to be statistically different.

Keywords: breast, tumours, diameter

\section{Sažetak}

Prospektivnom studijom, koja je trajala od januara 2010.godine do januara 2015. godine, obuhvaćene su pacijentkinja lečene od karcinoma dojke. Pacijentkinje su podeljene u 2 grupe. Prvu, grupu A (68 pacijentkinja), činile su pacijentkinje kojima je otkriven tumor dijametra do $2 \mathrm{~cm} \mathrm{i} \mathrm{koje} \mathrm{su} \mathrm{ope-}$ risane poštednom metodom. Drugu, grupu B (88 pacijentkinja), činile su pacijentkinje kojima je otkriven tumor dijametra preko 2 cm i kojim je dojka amputirana u okviru radikalne operacije karcinoma procedurom po Madenu.

Cilj rada je analiza efekata hirurškog lečenja karcinoma dojke različitog dijametra i uticaja dijametra tumora na ishod lečenja.

Parametri za poređenje rezultata bili su broj recidiva, vreme proteklo od operacije do recidiva i ishod. U pogledu motiva za dolazak na pregled dojki nije bilo statistički značajne razlike među ispitivanim grupama. Incidenca karcinoma u levoj ili desnoj dojci takođe nije pokazala statističku razliku.

Utvrđeno je da je karcinom dojke najčešći kod žena u dobi između 50-70 godina starosti. Pokazalo se da je karcinom dojke kod pacijentkinja u dobi 71-80 godina starosti znatno češće bio promera preko $2 \mathrm{~cm}$. Recidiv obolenja registrovan je u 3 slučaja kod pacijentkinja grupe A. Recidiv u grupi B nije registrovan. Letalni ishod je zabeležen u grupi B u 4 slučaja a u grupi A u 1 slučaju što se pokazalo statistiki različitim.

Ključne reči: dojka, tumori, dijametar

\section{INTRODUCTION}

Breast carcinoma is the first on the list of malignancy in women. According to current estimates, in countries that have a central register of malignancy, $20-25 \%$ of tumors are breast tumors, while the lethal outcome after contracting the disease is $15-20 \%$ (1).

Such high percentages can be even higher. The disease outcome can be improved only if the elements, pointing to timely diagnosis have been learnt, as well as predisposing and risk factors.
All predisposing risk factors have known nowadays are questionable and consensus on many of them does not exist. In fact, there is a mathematical fact that many women who were diagnosed with breast carcinoma, over $70 \%$ of them no history of risk factors for breast cancer $(2,3)$.

The largest number of breast carcinoma occurs in the structures of lobular units of terminal ducts, which are peripheral tumor localizations. The most common location of breast malignancy is in the upper outer quadrant $(40 \%)$, then in the central zone (30\%), upper inner 
quadrant (15\%), the lower outer quadrant (10\%) and the lower inner quadrant (5\%).

According to the cascade theory, when breast carcinoma is in the stage of „in situ“, or it is a minimum cancer without lymphatic metastases, it is characterized as a local disease. When metastatic tumors are proved, breast cancer is treated as systemic disease.

According to experimental data, the average time of doubling the volume of breast malignancy is 100 days. It results to pass about 6-7 years until the tumor reaches a volume when palpable. Sometimes, in the case of some tumors, this period is much longer (3).

Local tumor progression involves penetration along the connective septum and breast ducts. The tumor spreads through the lymphatic vessels, then infiltrates the blood vessel walls, penetrating into the lumen of the same and infiltrates the fatty tissue of the breast.

Infiltration of the deep lymphatic of dermis causes edema of the skin, which, when expressed, it looks like orange peel. When the tumor is fixed to the skin, it is manifested as a local erythema with subsequent ulceration.

Regional metastases affect the axillary lymphatics (when the primary tumour localized in the upper outer quadrant) and along the inner a. Mamaria (when the primary tumours localized in the area of inner quadrants and central zone) (3).

The incidence of lymphadenopathy in axilla is about in $70 \%$ of cases and is directly related to the size of tumour in the breast. The degree of involvement of axillary lymphatic by levels is of huge importance. Manifested lymphadenopathy in the clavicle zone usually implies distant metastases.

Visceral metastases are the result of hematogenous dissemination. The incidence of visceral metastases in the liver is about $59 \%, 44 \%$ in skeleton, pleura $36 \%$, skin $35 \%$, and adrenal glands $31 \%$. Lobular breast carcinoma can give metastases with completely atypical localizations. The fact, that visceral metastases can be found even at the primary tumour with small dimensions, indicates on thankless prognosis when we talk about breast cancer $(4,5)$.

\section{Aim OF THe STUdY}

The aim is to analyse the effects of surgical treatment of breast carcinoma with different diameter and influence of the tumour diameter to the outcome of treatment.

\section{MATERIAL AND METHODS}

The prospective study, lasted from January 2010 to January 2015, covered the respondents treated for breast carcinoma. The respondents were divided into 2 groups. First group, group A (59 respondents), included the respondents where the tumour was found in diameter to $2 \mathrm{~cm}$ and were operated by breast-sparing surgery. Second group, group B (88 respondents), was consisted of respondents where the tumour was discovered in diameter over $2 \mathrm{~cm}$ and which breast amputated as part of a radical carcinoma surgery by Madden technique.

The observed parameters were the motive of the respondents for visiting doctor for examination and age of respondents (Table 1, Table 2 and Table 3). Parameters for the comparison of results were disease recurrence, time from treatment to recurrence and possible lethal outcome.

Table 1. Distribution of respondents by age

\begin{tabular}{|c|c|c|}
\hline Age & Group A & Group B \\
\hline $30-40$ & $7(10,2 \%)$ & $5(5,7 \%)$ \\
\hline $41-50$ & $9(13,3 \%)$ & $11(12,5 \%)$ \\
\hline $51-60$ & $19(27,9 \%)$ & $26(29,5 \%)$ \\
\hline $61-70$ & $23(33,8 \%)$ & $25(28,5 \%)$ \\
\hline $71-80$ & $6(8,9 \%)$ & $19(21,5 \%)$ \\
\hline $81-90$ & $4(5,9 \%)$ & $2(2,3 \%)$ \\
\hline Total & $68(100 \%)$ & $88(100 \%)$ \\
\hline
\end{tabular}

Table 2. Respondents motive for examination

\begin{tabular}{lcc} 
Motive for examination & Group A & Group B \\
\hline Regular control & $1(1,5 \%)$ & $0(0 \%)$ \\
\hline Palpable mass reminds tumour & $58(85,3 \%)$ & $78(90,9 \%)$ \\
\hline Pain in the breast & $8(11,7 \%)$ & $8(9,1 \%)$ \\
\hline The discharge from the nipple & $1(1,5 \%)$ & $2(2,2 \%)$ \\
\hline Total & $68(100 \%)$ & $88(100 \%)$
\end{tabular}

Table 3. Distribution of respondents to the side of the tumour

\begin{tabular}{lcc|}
\hline Side & Group A & Group B \\
\hline Left breast & $38(55,8 \%)$ & $41(\%)$ \\
Right breast & $29(42,7 \%)$ & $46(\%)$ \\
Both breasts & $1(1,5 \%)$ & $1(\%)$ \\
Total & $68(\%)$ & $88(\%)$
\end{tabular}

\section{RESULTS}

The research results are shown in Table 4, Table 5, Table 6 and Graph 1. The parameters for comparison were: recurrence, time elapsed from surgery to recurrence and lethal outcome. 
Table 4. Recurrence

\begin{tabular}{|lrc|}
\hline Recurrence & Group A & \multicolumn{1}{c|}{ Group B } \\
\hline Yes & $3(4,5 \%)$ & - \\
No & $65(95,5 \%)$ & - \\
Total & $68(100 \%)$ & $88(100 \%)$ \\
\hline
\end{tabular}

Table 5. Time elapsed from surgery to recurrence

\begin{tabular}{|lcc|}
\hline Months & Group A & Group B \\
& 30 & - \\
& 26 & - \\
\hline Average & 24 & \\
\hline
\end{tabular}

Table 6. Lethal outcome

\begin{tabular}{|lcc|}
\hline Lethal outcome & Group A & Group B \\
\hline Yes & $1(1,5 \%)$ & $4(\%)$ \\
\hline No & $67(98,5 \%)$ & $84(\%)$ \\
Total & $68(100 \%)$ & $88(100 \%)$ \\
\hline
\end{tabular}

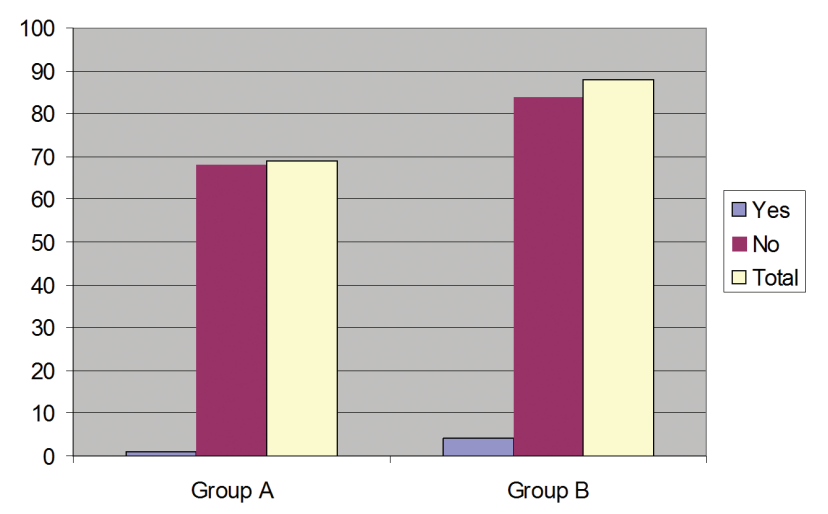

Graph 1. Lethal outcome

\section{Statistical analysis between the groups A and B are as follows:}

- In terms of the characteristics of the age of the respondents - group with age of 71 to 80 , there is a statistically significant difference $(\mathrm{p}<0.01$, reliability 99\%), $\mathrm{Z}=2.46324$

- In terms of the characteristics of recurrence, there was a statistically significant difference $(\mathrm{p}<0.01$, reliability 99\%), $\mathrm{Z}=2.057532$

- In terms of the characteristics of lethal outcome there is a statistically significant difference ( $p<0.01$, reliability $99 \%), \mathrm{Z}=2.647848$

\section{Discussion}

The analysis included 156 women who are suffering from breast carcinoma. The youngest respondent is 36 and the oldest 85 . Our research has shown that breast carcinoma most common in the age of 51-70 which is a $59,6 \%$. This data is consistent with data from the available literature.
Most women with breast cancer (75-80\%) make an appointment for the examination after they notice palpable tumour. Characteristic findings breast carcinoma is generally described as a palpable tumour of rigid consistency, mainly fixed in the breast and usually unclear boundaries (4).

Most of respondents, during our analysis, came for examination because of palpable mass reminds tumour of breast.

In addition to the above, there is also characteristic the unilateral retraction of the nipple or skin that is mainly due to catching and spreading along the Cooper's ligaments and rarely because of direct invasion of the tumour. For about $50 \%$ of cases, when breast cancer was diagnosed, it is accompanied by regional lymphadenopathy (5).

At our respondents in group A there was 25 (36,7\%) peripheral lymphadenopathy, and in Group B 39 (44,3\%).

Breast carcinoma for a long time does not give any special characteristic clinical features and it is not palpable for a long years. When it is palpable looks like rigid node, limited mobility, often irregular. There is no any dynamic volume changes related to menstrual cycle. Main problems are pain in about $15 \%$ manifested as burning sensation and annealing in the region of the areola and nipple and/or secretion from the nipple occurs in about $8-17 \%$ of cases. One of the symptoms in the clinical feature is retraction of nipple or pulled in. Lymphadenopathy in the area of axilla is common in the clinical feature $(4,5)$.

At 8 respondents in group A, except palpable mass reminds tumour, there was a discrete pain in the breast, while in group $B$ also 8 respondents reported pain in the breast and in 2 respondents was recorded a retraction and discharge from the breast.

The incidence of tumours in the left or right breast (or both) is very similar in both the observed group of respondents.

The earlier diagnosis of the disease (in the early stages, in the zero or initial clinical stage of disease) and all modern radiotherapy and neoadjuvant chemotherapy in the past few decades, allow sparing approach to breast carcinoma surgery. This includes locally optimal radical excision of tumour to the healthy part, and taking care of aesthetic appearance of the breast after tumour excision. Functional dissection of armpits has to be also performed, with additional postoperative radiation therapy. Additional chemotherapy should be given after $\mathrm{PH}$ tumour results and lymphatics and after the determination of hormone receptors (6). 
Breast-sparing surgery can be performed in situations of nonpalpable tumour findings in zero phase, or in the stage of T0, Tis, N0, M0, then the first stage T1, a, b, c, N0, M0, as well as in stage of T1, N1, M0.

Breast-sparing surgery (quadrant resection), with axillary dissection of homolateral axilla, is indicated in case of ductal carcinoma of the diameter up to $2.5 \mathrm{~cm}$, localized in the outer quadrant with no palpable axillary lymph nodes (T up to $25 \mathrm{~mm}, \mathrm{No})(3,7)$.

Therefore, sparing surgery can be performed at the stage of disease with small T2 tumours, which is less than 30 $\mathrm{mm}$, of course, only when there are no solid metastases in lymph nodes (7).

Quadrantectomy with axillary dissection is contraindicated in case of histologically proven lobular carcinoma, given that it has a tendency to multicentric development. The carcinoma localization in the medial or central quadrant of the breast prejudice modified radical mastectomy (Madden, Patey), while Quadrantectomy with axillary dissection in that case is not indicated (7).

Our respondents in group A had breast carcinoma with diameter up to $2 \mathrm{~cm}$ and they were operated by breast-sparing surgery with very good aesthetic appearance of operated breast.

Tumours with $3 \mathrm{~cm}$ in diameter can be performed 3-4 cycles of chemotherapy to try to reduce tumour to $50 \%$ of size. A good therapeutic response and the said tumour reduction to $50 \%$, the patient is placed in a zone of operability sparing technique.

Exceptionally, sparing surgery may be considered at the tumour is larger than $3 \mathrm{~cm}$ if it is placed in extremely large breasts. Of course, this operation can be also performed at the explicit request of the patient when not permitted radical mastectomy (8).

Finally, sparing surgery is not indicated for tumours larger than T2. The contraindication for such tumours implies regardless of preoperative lymph nodes status.

Sparing surgery is not also indicated in the case of recurrence after breast-sparing surgery as well as in the case of multifocal tumours (8).

Nowadays worldwide, there is a tendency to decrease radicalism of surgical procedures of the breast carcinoma and more frequent use of less radical, modified radical mastectomy (Patey, Madden, Handley, Auchincloss).

Trend of avoid radical mastectomy was primarily the result of new information on the mechanism of the malignancy development in the breast. A large number of surgeons address the issue of those reasonable operating procedures designed to reduce radicalism and at the same time can achieve the optimal therapeutic effect as well as with the radical mastectomy, following Halsted (3).

Our respondents of group B were operated by Madden surgical technique (9). In the context of this procedure it was done a complete amputation of the breast and dissection of armpit to the level of the second floor of axilla. Radical dissection of all armpits floors does not provide a global or a local benefit, so that two-thirds of axillary dissection, as a compromise of radicalism, is probably more optimal. In this case, dissection should be done from the lateral edge of $\mathrm{m}$. Pectoralis minor, and neurovascular plexus (a. and v. axillaris, plexus brachialis) is preserved and the risk of postoperative edema of upper limb is reduced to a minimum. This level radicalism, at axilla dissection, can be observed as a functional dissection. We have been sparing the small pectoral muscle and all pectoral muscle innervation with this kind of surgery.

After breast cancer surgery, in a number of patients is coming to the recurrence of disease. Women had be underwent partial resection of the breast, tumorectomy with wide excision (quadrantectomy, segmentectomy), with additional radiation therapy, recurrence rate is about $10-15 \%$ in the postoperative period of 10 years $(10,11)$.

Relapse can occur in the operational zone of the scar, on the chest or in the axillary region. Relapse is usually clinically manifested as ulceration node, with or without local infiltration of the skin and subcutaneous tissue. It is assumed that this type of recurrence occurs due to insufficiently radical excision of the primary tumour or histologically positive lymph node, then due to intraoperative implantation of malignant cells or cause cutting of lymphatic and scattering of embolism of malignant cells.

Postoperative radiotherapy can neutralize malignant cells in treated area, scattered during surgical manipulation and sterilize the tissue on resection lines, which can reduce the recurrence to $28-30 \%(12,13)$.

Recurrent of tumours in our subjects in group A was registered in 3 cases which required optimal radical reoperation. In respondents from group B there was no local recurrence of the tumour.

The highest percentage of relapses occurs in the first two years after the initial surgical treatment, although it can occur even after several years. Numerous reports indicate that the frequency of relapses in direct correlation with the size of the primary tumour, as well as the number of affected and histologically positive axillary lymph nodes (14). 
In our respondents from group $\mathrm{A}$, time elapsed from surgery to recurrence accounted for 24,26 and 30 months, average 26,6 months, which is about same with data from literature.

We should careful and periodically follow up the operated patients for early detection of recurrence. Each suspected mass reminds tumour and infiltrate in the operated area should be excised and histologically verified (3).

A possibility of cure of each patient largely depends on the extent and stage of disease, despite the better possibilities of treatment. Breast carcinoma is diagnosed at an early stage, for many women, when it can be completely cured. However, in $24-30 \%$ of women with a nodule-negative disease and in $50-60 \%$ of the nodule positive disease relapse will be developed. In $6-10 \%$ of cases, metastatic disease will be diagnosed initially, at the time of diagnosis (14).

After primary treatment relapse occurs in $10-30 \%$ of patients in stage I, (over 10 years follow-up) and $40-50 \%$ in stage II. In about $85 \%$ of cases, relapse occurs within five years of diagnosis (15).
Mortality from breast carcinoma is still a large even in developed countries and it is about 40/100000 of women $(15,16)$.

There was one case lethal outcome in order to breast cancer in our respondents in group A during the period of this study. In group B, there were 4 women with lethal outcome, which showed statistically significantly different.

\section{ConClusion}

There were no significant differences between the two groups regarding the motives for attending breast examination. The incidence of carcinoma in the left or right breast also showed no statistical difference.

It was found that the most common breast carcinoma is in women age between 50 and 70. It has been shown that breast carcinoma with diameter over $2 \mathrm{~cm}$ was significantly more frequent in women age of 71 to 80 (group B). Recurrent disease was registered in 3 cases in respondents from group A. Recurrence in group B was not registered. Lethal outcome was observed in group B in 4 cases, and in group A in 1 case, which proved to be statistically different.

\section{References}

1. Esther M, John I, Amanda I, Phipps I, et al. Medical radiation exposure and breast cancer risk: Findings from the Breast Cancer Family registry. Int J Cancer, 2007;(121):386-394

2. Jemal A, Siegel R, Ward E, et al. Cancer statistics 2010. Ca Cancer j Clin. 2010;60(5):277-300

3. Lukic D, Lazic P. Hirurgija tumora dojke, Medicinski fakultet Banja Luka, 2013.

4. Watson M. Assessment of suspected cancer. InnoAiT, 2008;1(2):94-107.

5. Lacroix M. Significance, detection and markers of disseminated breast cancer cells. Endocrine related Cancer, 2006;3(4):1033-67

6. Elias D, Baton O, Sideris L, Matsuhisa T, Pocard M, Lasser P. Local recurrences after intraoperative radiofrequency ablation of liver metastas es: a comparative study with anatomic and wedge resections.Ann Surg Oneal, 2004;11(5):500-5

7. Giordano S.H. Update on Locally Advanced Breast Cancer. Oncologist, 2003;8:521-530

8. Hortobagyi G N. The Curability of Breast Cancer: Present and Future. Eur J Cancer, 2003; 1:24-34

9. Radan Džodić, Hiruirgija raka dojke, Dosije, Beograd 2005.

10. Elias D, Baton O, Sideris L, Matsuhisa T, Pocard M, Lasser P. Local recurrences after intraoperative radiofrequency ablation of liver metastas es: a comparative study with anatomic and wedge resections.Ann Surg Oneal, 2004;11(5):500-5
11. Wolff AC, Davidson NE. Preoperative Therapy in Breast Cancer: Lessons from the Treatment of Locally Advanced Disease. Oncologist, 2002;7:239-245

12. Husain ZA, Mahmood U, Hanlon A, et al. Accelerated partial breast irradiation via brachytherapy: a patterns of care analysis with aSTrO consensus statement groupings. Brachytherapy. 2011; 10(6):479-85

13. Vaidya JS, Joseph DJ, Tobias JS, et al. Targeted Intraoperative radiotherapy Versus Whole Breast radiotherapy for Breast Cancer (TarGIT-a trial): an international, prospective, randomised, noninferiority Phase 3 trial. Lancet, 2010; 376:91-102

14. Hendrick RE. Radiation doses and cancer risks from breast imaging studies. Radiology, 2010;257(1):246-53

15. Thomssen C. Perspectives on Breast cancer Management: Tailoring Treatment to the Individual Patient. Breast care, 2008;3:21-21

16. Untch M, Rezai M, Loibl S et al. Neoadjuvant treatment with trastuzumab in HEr2 positive breast cancer: results from the GeparQuattro study. J Clin Oncol, 2010; 28(12):2024-31 